\title{
Effects of Credit Risk Management on Performance of Banks in
} Kenya

\author{
George Onyango Odawo \\ School of Human Resource Development, \\ Department of Entrepreneurship and Procurement, Leadership and management. \\ Jomo Kenyatta University of Agriculture and Technology, Nairobi Kenya. \\ Dr. Elizabeth Nambuswa Makokha \\ School of Human Resource Development, \\ Department of Entrepreneurship and Procurement, Leadership and management. \\ Jomo Kenyatta University of Agriculture and Technology, Nairobi Kenya. \\ Prof. Gregory Namusonge Prof. \\ School of Human Resource Development, \\ Department of Entrepreneurship and Procurement, Leadership and management. \\ Jomo Kenyatta University of Agriculture and Technology, Nairobi Kenya.
}

\begin{abstract}
The purpose of study was to analyze the effects of credit risk management on performance of banks in Kenya. The study was guided by the following specific objective; to determine the effects of on bank performance in Kenya. Lending is an investment and therefore as the bank constructs a portfolio it considers an "efficient frontier" of optimal portfolios, offering the maximum possible expected return for a given level of risk. The study was based on modern portfolio, capital asset pricing and liquidity preference theories. It considered the credit scoring model as statistical analysis used by banks to evaluate worthiness of a borrower. The target population of interest was 44 commercial banks categorized into 28 local and 16 foreign banks. They are also categorized into small, medium and large banks. The study used census survey because of the small population. The questionnaires were administered to all respondents of commercial banks in Kenya. Piloting was done to check reliability and validity of data collection and instruments. Data was coded, edited to bring meaning. Multiple regression was also used to test the significance of one variable to the others. Additional secondary data in form of annual reports and financial statements were obtained from Central Bank of Kenya for the period 2011 to 2016. Data collected was analyzed using SPSS version 21.The null hypothesis that liquidity do not have statistically significant influence on of banks performance in Kenya was rejected. Therefore, the independent variable had significant influence on banks performance in Kenya. The bank should take into consideration potential future changes in economic conditions when assessing individual credits and their credit portfolio. The study is significant especially to decision makers involved in the implementation of credit risk management for their banks. The credit managers are able to make strategic, tactical and operational decisions based on the results of a scientific study rather than relying on trial and error.
\end{abstract}

\section{INTRODUCTION}

The growth of credit risks in financial institutions globally and locally, and the rise of commercial economies have changed the role of credit risk management in the banking industry. According to Jamaat and Asgari (2010) banks are investing a lot of funds in credit risk management modeling. Skills in risk-focused supervision are continually being developed while exposing supervisors to relevant training (Kithinji 2010). By adopting this approach, the banking industry, and specifically the small banks are sensitized on the need to have formal 
and documented risk management frameworks (De Juan 1991). Good risk management is not only a defensive mechanism, but also an offensive weapon for commercial banks and this is heavily dependent on the quality of leadership and governance. Jorion (2009) notes that a recognized risk is less "risky" than the unidentified risk.

Financial institutions are exposed to a variety of risks among them; interest rate risk, foreign exchange risk, political risk, market risk, liquidity risk, operational risk and credit risk (Yusuf 2003). In some instances, commercial banks and other financial institutions have approved decisions that are not vetted; there have been cases of loan defaults and nonperforming loans, massive extension of credit and directed lending. The Basel Committee (2000) suggests that liberalized loaning, bad management of credit portfolio, insufficient evaluation of changing economies create a lot of problems for financial institutions. It has been noted with a lot of concern that the more complex a risk type is the more specialized, concentrated and controlled its management must be (Seppala 2000). Risk management is defined as the process that a bank puts in place to control its financial exposures. The process of risk management comprises the fundamental steps of risk identification, risk analysis and assessment, risk audit monitoring, and risk treatment or control (Bikker and Metzmakers 2005). This shows that Credit risk is still considered the most significant risk that commercial banks face, (Bis. Org; 2014) thus supplying the foundation for new business models, new business processes and new ways of credit risk management. This for instance has led to the banking sector mispricing of credit and liquidity risk, inadequate liquidity buffers and excess credit growth.

According to the Basel Accords (1999), a global regulation framework for financial institutions, credit risk is one of the three fundamental risks a bank or any other regulated financial institution has to face when operating in the markets (the two other risks being market risk and operational risk). As the 2008 financial crisis has shown us, a correct understanding of credit risk and the ability to manage it are fundamental in today's world.

The worldwide credit crunch, which started in 2006 with sub-prime mortgages in the United States, has highlighted the fundamental importance of the credit decision. As the problems in these mortgages unfolded, it was demonstrated that unsound credit decisions had been made and lessons as to how to manage credit risk effectively had been either ignored or never learned. This shows that poor lending decisions, whether by a financial institution or a corporate, can lead to significant losses. Being able to manage this risk is a key requirement for any lending decision. It should also be well understood by industrial and commercial firms that, in the course of their normal business, provide trade credit.

While financial institutions have faced difficulties over the years for a multitude of reasons, the major causes of serious banking problems continue to be directly related to lax credit standards for borrowers, poor risk management or lack of attention to changes in economic environment. The goal of credit risk management is to maximize a bank's risk-adjusted rate of return by maintaining credit risk exposure within acceptable parameters. Banks need to manage the credit risk inherent in the entire portfolio as well as the risk in individual credits or transactions. Banks should also consider the relationships between credit and other risks. The effective management of credit risk is a critical component of a comprehensive approach to risk management and essential to the long term success of any banking organization.

Since exposure to credit risk continues to be the leading source of problems in banks worldwide, banks and their supervisors should be able to draw useful lessons from past experiences. Banks should now have a keen awareness of the need to identify, measure, monitor and control 
credit risk as well as to determine that they hold adequate capital against these risks and that they are adequately compensated for risks incurred. The Basel Committee is issuing this document in order to encourage banking supervisors globally to promote sound practices for managing credit risk. Although the principles contained in this paper are most clearly applicable to the business of lending, they should be applied to all activities where credit risk is present.Efficiency measurement is one aspect of investigating a firm's performance. Efficiency can be measured in three ways; maximization of output, minimization of cost, and maximization of profits. In general, efficiency is divided into two components (Kumbhakar and Lovell, 2003). A firm is regarded as technically efficient if it is able to obtain maximum outputs from given inputs or minimize inputs used in producing given outputs. The objective of producers here is to avoid waste.

Regional and national governments play a key role in promoting the adoption of e-commerce technology in order to keep up with the evolving trends of the information age. In line with these, they are ever in search of ways to utilize this technology to improve efficiency and effectiveness in the management of credit risk. According to Bleim (2001) most of systematic banking crisis arise because of enormous portfolios of bad loans. Dionne (2005) emphasizes on the importance to evaluate whether risk of a particular loan is risk of the whole portfolio. An effective Credit Risk Management (CRM) government thus requires well defined procedures and methods, for instance, technology to effectively protect loans from credit risk.

For most banks, loans are the largest and most obvious source of credit risk; however, other sources of credit risk exist throughout the activities of a bank, including in the banking book and in the trading book, and both on and off the balance sheet. Banks are increasingly facing credit risk in various financial instruments other than loans, including acceptances, interbank transactions, trade financing, foreign exchange transactions, financial futures, swaps, bonds, equities, options, and in the extension of commitments and guarantees, and the settlement of transactions.

The government of Kenya, like most governments, has also launched several initiatives regarding CRM. The Central Bank of Kenya (CBK) has the regulatory authority over commercial banks, micro-finance institutions and forex bureaus. As at December 2016, Kenya had 43 licensed commercial banks and one Mortgage Company; CBK, 2016. Out of the total 44 institutions, 28 are locally owned and 16 are foreign owned. Since 2005, commercial banks have embarked upon upgrading their risk management and control systems (CBK, 2010). This was after the issuance of the Risk Management Guidelines (RMG) in 2005 and the adoption of the Risk Based Supervision approach to supervising financial institutions in 2005. Despite these approaches in credit risk management it is not clear to what extent it has impacted on profitability.

Morris (1987) presents one of the earliest studies on the relationship between nonperforming loans and credit risk management. They reported that banks with greater risk appetite tend to record higher losses in terms of non-performing loans and provisions. For instance a study by Haneef et al (2012) concluded that non-performing loans are increasing due to inadequate risk management which threatens the profitability of banks. The adoption of CRM would only be successful through the experience of the giant commercial banks in credit risk management policies adoption and implementation and their joint efforts with the government, OJ Ochola (2010). However, such efforts can be hurt by unenlightened government policies, politics and other constraints faced by government organizations such as lack of resources, bureaucratic regulations and legislative requirements. This opens up the experience of government leaders in CRM that can also be researched. 
According to Central Bank Supervisory Report, (CBK, 2005), CBK has a priority initiative over commercial banks towards the application of various credit risk management methods such as credit limits, taking collateral, diversification, loan selling, syndicate loans, credit insurance and securitization and credit derivatives. These came about after many banks had collapsed in the 1990 s as a result of poor management of credit risk which was portrayed in high levels of nonperforming loans. Some of the loans were "political loans" granted with no security or credit assessment. The high levels of nonperforming loans subsequently eroded the profits through provisions. However, despite the stringent controls and measures put in place by the commercial banks in Kenya some banks make losses attributed to credit risk management.

Present day economy focus is about the customer on one hand and service provision on the other and of critical interest is for the services to be provided efficiently with a good understanding of the customer and service offering entities Cabinet Office(2004). Initiatives that lead to the launch of effectiveness of CRM on profitability particularly through the development of a sound credit policy that would help improve prudential oversight of asset quality, establish a set of minimum standards and apply a common language and methodology (assessment of risk, pricing, documentation, securities, authorization and ethics) for measurement and reporting of non-performing assets, loan classification and provisioning pose both significant achievements and challenges. Effective and operational credit policy sets out the bank's lending philosophy and specific procedures and means of monitoring the lending activity. For instance, the guiding principle in credit appraisal should ensure that only those borrowers that require credit and are able to meet repayment obligation can access credit; CBK Annual Supervision Report CBK(2000).

The government of Kenya, like most governments, has also launched several initiatives regarding CRM. The Central Bank of Kenya (CBK) has the regulatory authority over commercial banks, micro-finance institutions and forex bureaus. As at December 2016, Kenya had 44 licensed commercial banks and one Mortgage Company; (CBK, 2016). Out of the total 44 institutions, 28 are locally owned and 16 are foreign owned. Since 2005, commercial banks have embarked upon upgrading their risk management and control systems (CBK, 2010). This was after the issuance of the Risk Management Guidelines (RMG) in 2005 and the adoption of the Risk Based Supervision approach to supervising financial institutions in 2005. Despite these approaches in credit risk management it is not clear to what extent it has impacted on profitability.

Morris (1987) presents one of the earliest studies on the relationship between nonperforming loans and credit risk management. They reported that banks with greater risk appetite tend to record higher losses in terms of non-performing loans and provisions. For instance a study by Haneef et al (2012) concluded that non-performing loans are increasing due to inadequate risk management which threatens the profitability of banks. The adoption of CRM would only be successful through the experience of the giant commercial banks in credit risk management policies adoption and implementation and their joint efforts with the government, OJ Ochola (2010). However, such efforts can be hurt by unenlightened government policies, politics and other constraints faced by government organizations such as lack of resources, bureaucratic regulations and legislative requirements. This opens up the experience of government leaders in CRM that can also be researched.

According to Central Bank Supervisory Report, (CBK, 2005), CBK has a priority initiative over commercial banks towards the application of various credit risk management methods such as credit limits, taking collateral, diversification, loan selling, syndicate loans, credit insurance and 
securitization and credit derivatives. These came about after many banks had collapsed in the 1990s as a result of poor management of credit risk which was portrayed in high levels of nonperforming loans. Some of the loans were "political loans" granted with no security or credit assessment. The high levels of nonperforming loans subsequently eroded the profits through provisions. However, despite the stringent controls and measures put in place by the commercial banks in Kenya some banks make losses attributed to credit risk management.

The past studies in this field have looked at general effects and relationships between risk management and profitability in financial institutions such as the research done by Githaiga (2013), Kithinji (2010), Achou (2008) etc.The objective in this study will be to ascertain the effectiveness of credit risk management on profitability of commercial banks. On the other hand, risk management is focused on minimizing large losses arising from loans. The management needs to identify the risk, measure and quantify the risk then develop strategy to manage it. The global financial system has got into a new regime -the IFRS 9 which took effect from January $1^{\text {st }}$.Under the IFRS 9 , the fundamental change is the recognition of credit risk losses. Previously, financial institutions would recognize a risk at the point of default. They will be expected to recognize this at the beginning and during the loan's life cycle and make the necessary provisions.

Profitability is an indicator of banks' capacity to carry risk and/or increase their capital base. It indicates banks' competitiveness and measures the quality of management. Profitability is one of the key concepts in our research. This is due to the fact that the topic of this research is about effectiveness of credit risk management on profitability of commercial banks. Clear explanation to the profitability of commercial banks is crucial for readers to understand the research procedure and meanings. Profitability of banks is measured by return on assets (Flamini et al., 2009 Oladele et al., 2012), return on equity (Saona,2011) or the net interest margin ( Naceur \& Goaied ,2008; Naceut \& Omran 2011;Sufian \& Habibullah,2009).

Credit risk is the potential that a contractual party will fail to meet its obligations in accordance with the agreed terms. Credit management is one of the most important functions in a business enterprise. It is critical for purposes of stability, profitability and growth of a firm. Despite great efforts made by commercial banks, credit risk is still a challenge due to increasing marginal losses that arise when borrowers default. While financial institutions have faced difficulties over the years for a multitude of reasons, the major causes of serious banking problems continue to be directly related to lax credit standards for borrowers due to poor management. The goal of credit risk management is to maximize a bank's risk-adjusted rate of return by maintaining credit risk exposure within acceptable parameters. Banks need to manage the credit risk inherent in the entire portfolio as well as the risk in individual credits or transactions. However, there have been complaints about inability to meet obligations, inadequate controls, and high rate of defaulters among others. Therefore, the study sought to analyze effects of credit risk management on banks' performance. The specific objectives of the study was to determine the effects of liquidity on banks' performance in Kenya.

\section{LIQUIDITY MANAGEMENT}

Liquidity is the ability of a bank to fulfill its obligations, especially the depositors. According to Dang (2011) adequate level of liquidity is positively related with bank performance. The most common ratio to measure performance are customer deposit to total assets and total loan to customer deposits. The bank assets include among others current assets, fixed assets, credit portfolio and other investments. Loan of a bank is the major that generates the major share of income. Quality of loan portfolio determines the performance of banks. The highest risk facing a bank is the losses derived from delinquent loans (Dang, 2011). It is the major concern of all 
banks to keep the amount of defaulters' low level. Hence nonperforming loans to total loans shows that the good health of the portfolio of a bank. Deterioration of asset quality relates to increase in credit risk which reduces the expected profits.

Liquidity risk is considered as one of the serious concern and challenge for the modern era banks. A bank having good asset quality, strong earnings and sufficient capital may fail if it is not maintaining adequate liquidity. Liquidity held by commercial banks depicts their ability to fund increases in assets and meet obligations as they fall due. Liquidity is one of the important financial stability indicators since liquidity shortfall in one bank can cause systemic crisis in the banking sector due to their interconnected operations. Arising from the placement of Dubai Bank Ltd in liquidation and Imperial Bank Ltd in receivership, CBK closely monitored the banking sector particularly on liquidity and credit risks. Banks that faced liquidity challenges that were not able to access liquidity in the market used the liquidity facilities available at the CBK such as intraday liquidity facility, rediscount of government securities, open market operations and lender of last resort window. The liquidity challenges were primarily caused by liquidity segmentation in the inter-bank market.

The average liquidity ratio as at December 2015 stood at 38.1 per cent as compared to 37.7 per cent registered in December 2014. The increase in the ratio is mainly attributed to a higher growth in total liquid assets compared to the growth in total short-term liabilities. Total liquid assets grew by 13 per cent while total short-term liabilities grew by 12 per cent. The banking sector's average liquidity in the twelve months to December 2015 was above the statutory minimum requirement of 20 per cent. With prudent management of credit the cash out flows in terms of credit risk will be less than cash inflows from repayments of loans.

Banks, as the critical part of financial system, play an important role in contributing to a country's economic development. If the banking industry does not perform well, the effect to the economy could be huge and broad. Studies on performance of banking institutions are plenty. Results of these studies strongly suggest that bank profitability determinants vary across countries and also among regions of the world (Doliente, 2003). In accordance with the study of Grier (2007), profitability ratios are often used in a high esteem as the indicators of credit analysis in banks, since profitability is associated with the results of management performance. Bank performance indicates bank's capacity to generate sustainable profits. Banks protect the profitability against unexpected losses, as it strengthens its capital position and improves future profitability through the investment of retained earnings. A bank that persistently makes a loss will ultimately deplete its capital base, which in turn puts equity and debt holders at risk. Inorder to create shareholder value, bank's return on equity (ROE) needs to be greater than its cost of equity.

Return on equity, ROE, and return on assets, ROA, are the most commonly used ratios, and the quality level of ROE is between $15 \%$ and $30 \%$, for ROA is at least $1 \%$. Wong et al., (2008) indicated that the efficiency of banks can be measured by using the ROE which illustrates to what extent banks use reinvested income to generate future profits. According to Riksbank's Financial Stability Report (2002), the measurement of connecting profit to shareholder's equity is normally used to define the profitability in the banks. Jensen Investment Management (2008) mentioned that ROE provides a very useful gauge of profit generating efficiency because it measures how much earnings a company can get on the equity capital.

According to the introduction of DuPont model, Return on Equity (ROE) value the overall profitability of the fixed income per dollar of equity (Saunders \& Marcia, 2011). ROE value the 
overall profitability of fixed income per shilling of equity. The shareholders of banks prefer higher ROE. However, increasing ROE demonstrates increasing risk for instance when total equity capital decreases relative to net income, ROE will have an increasing under the constant net income. A large drop in equity capital may result in violation of minimum regulatory capital requirement and therefore increase the risk of insolvency of the bank (Saunders \&Marcia, 2011

ROA here determines the net income produced per shilling of assets. EM measures the dollar value assets funded with each shilling of equity capital (Saunders \& Marcia, 2011, p. 24). The higher EM ratio indicates the more leverage (or debt) that is used by banks to fund its assets ((Saunders \& Marcia, 2011, p. 24). High EM ratio and ROA ratio have positive influence on ROE ratios (Saunders \& Marcia, 2011, p. 24). However, whenever there is a high ROE; it should be of concern to the bank's manager. For example, increasing EM generates increasing ROE ratio while the leverage of bank has also enhanced, which causes solvency risk (Saunders \& Marcia, 2011).

DuPont model is a fundamental performance measurement framework popularized by the DuPont Corporation. DuPont analysis is a useful technique used to decompose the different drivers of the return on equity. Decomposition of ROE allows investors to focus their research on the distinct company performance indicators otherwise cursory evaluation. According to DuPont analysis, there are three major financial metrics drive return on equity (ROE): operating efficiency, asset use efficiency and financial leverage. Operating efficiency is represented by net profit margin or net income divided by average shareholders' equity. Asset use efficiency is measured by total asset turnover. Finally, financial leverage is analyzed through observation of changes in the equity multiplier. If ROE is unsatisfactory, the DuPont analysis helps locate the part of the business that is underperforming.

DuPont method was developed in 1918 by an engineer at DuPont who noticed that the product of two common computed ratios, net profit margin and total assets turnover, equals return on assets (ROA). Almazari (2012,) introduces that DuPont model was created in the early 1990s but is still widely used for financial analysis due to the elegance of ROA being affected by a profitability measure and efficiency measure. In the 1970s, the concentration in financial analysis shifted from return on asset (ROA) to return on equity (ROE) Almazari (2012). Based on this fact, we consider using the model for seeking the appropriate indicators of profitability of commercial banks in Kenya. According to Saunders \& Marcia (2011) and Rudra (2009), ROE model for financial institutions based on DuPont system will be adopted. ROE is firstly decomposed into ROA and equity multiplier (assets/equity). ROA is decomposed further into net profit margin and total asset turnover. The profit margin allows the financial analysts to measure the income statement. And total assets turnover provides financial analysts a measure to evaluate the "assets" in the balance sheet. Equity multiplier presents the evaluation of the "liabilities and owners' equity" (Alimazari, 2012). Analysts can project the level of financial structure of financial institutions based on this system (Alimazari, 2012). Therefore, DuPont tool can provide financial analysts an efficient evaluation by decomposing the most frequently used measure of profitability, ROE to identify the strengths and weaknesses of the banks' performance (Saunders \& Marcia, 2011). Based on DuPont system, we prefer to choose ROE and ROA as the key indicators of performance.

\section{METHOD}

The study adopted a descriptive research design with a target population of 44 banks which consisted of locally and foreign owned banks and small, medium and large bank hence census. The major data gathering tool was a questionnaire. The first part of the questionnaire required 
relevant personal particulars of the respondents. The second part contains general risk management questions. The questionnaire were administered through drop and pick method so that the bank staff may get time to respond appropriately. piloting was done to test the validity and reliability of the research instrument. Data was analyzed by the use of descriptive statistics using SPSS and multiple regression analysis.

\section{DISCUSSIONS}

According to Jamaat and Asgari (2010), Liquidity held by commercial banks depicts their ability to fund increases in assets and meet obligations as they fall due. Liquidity is one of the important financial stability indicators since liquidity shortfall in one bank can cause systemic crisis in the banking sector due to their interconnected operations. Results on determine the effects of liquidity of banks performance in Kenya, the respondents were asked to indicate the level of agreeableness for liquidity on banks performance in Kenya and the findings are present in the table 4.1 below.

Table 4.1 Effects of liquidity of banks performance in Kenya

\begin{tabular}{|c|c|c|c|c|c|c|}
\hline Statement & SA & A & $\mathbf{N}$ & D & SD & Total \\
\hline $\begin{array}{l}\text { Bank have a sound credit management } \\
\text { system }\end{array}$ & 47.0 & 33.0 & 19.0 & 1.0 & 0 & 100 \\
\hline $\begin{array}{l}\text { The bank holds liquid assets which are } \\
\text { diversified }\end{array}$ & 35.0 & 42.0 & 4.0 & 10.0 & 8.0 & 99 \\
\hline $\begin{array}{l}\text { The bank hold cash (direct) bonds, as } \\
\text { well as making extensive use of } \\
\text { derivatives which are similarly } \\
\text { compared with other banks }\end{array}$ & 28.0 & 45.0 & 4.0 & 9.0 & 14.0 & 100 \\
\hline $\begin{array}{l}\text { The bank receive regular flows from } \\
\text { borrowers and has adequate cash } \\
\text { equivalents to meet demand any time }\end{array}$ & 25.0 & 48.0 & 6.0 & 20.0 & 1.0 & 100 \\
\hline $\begin{array}{l}\text { The staff do have experience on } \\
\text { dealing with previous liquidity issues }\end{array}$ & 30.0 & 33.0 & 10.0 & 20.0 & 7.0 & 100 \\
\hline $\begin{array}{l}\text { Debts due can be paid within the next } \\
12 \text { months }\end{array}$ & 11.0 & 20.0 & 12.0 & 40.0 & 17.0 & 100 \\
\hline $\begin{array}{l}\text { The banks credit risk strategy reflects } \\
\text { the banks tolerance for risk }\end{array}$ & 10.0 & 46.0 & 8.0 & 7.0 & 29.0 & 100 \\
\hline
\end{tabular}

The findings on whether bank have a sound credit management system showed that majority 33.0 percent of the respondents agreed while 47.0 percent strongly agreed that bank have a sound credit management system. 19.0 percent were neutral and 1.0 percent disagreed that bank have a sound credit management system. This means that in majority of respondents agreed that bank have a sound credit management system.

The findings obtained data on whether the bank holds liquid assets which are diversified. The results of data analysis results shows that majority 42.0 percent of respondents agreed while 35.0 percent strongly agreed that the bank holds liquid assets which are diversified. But 4.0 percent were neutral, 10.0 percent disagreed while 8.0 percent strongly disagreed. This implies that majority of the respondents agreed that the bank holds liquid assets which are diversified.

The results of the study on whether the bank hold cash (direct) bonds, as well as making extensive use of derivatives which are similarly compared with other banks also showed that majority 45.0 percent of the respondents agreed while 28.0 percent strongly agreed that the bank hold cash (direct) bonds, as well as making extensive use of derivatives which are similarly compared with other banks. But 4.0 percent were neutral, 9.0 percent disagreed and 
14.0 percent strongly disagreed. This shows that majority of the respondents agreed that the bank hold cash (direct) bonds, as well as making extensive use of derivatives which are similarly compared with other banks.

The findings further on whether the bank receive regular flows from borrowers and has adequate cash equivalents to meet demand any time showed majority 48.0 percent of respondents agreed while 25.0percent strongly agreed that the bank receive regular flows from borrowers and has adequate cash equivalents to meet demand any time. While 6.0 percent were neutral, 20.0 percent disagreed and 1.0 percent strongly disagreed. This shows that majority agreed that the bank receive regular flows from borrowers and has adequate cash equivalents to meet demand any time.

The results of the study on whether the staff do have experience on dealing with previous liquidity issues also showed that majority 33.0 percent of the respondents agreed while 30.0 percent strongly agreed that the staff do have experience on dealing with previous liquidity issues. But 10.0 percent were neutral, 20.0 percent disagreed and 7.0 percent strongly disagreed. This shows that slight majority of the respondents agreed that the staff do have experience on dealing with previous liquidity issues.

Further, the findings obtained data on whether debts due can be paid within the next 12 months. The results of data analysis results shows that majority 20.0 percent of respondents agreed while 11.0 percent strongly agreed that debts due can be paid within the next 12 months. But 12.0 percent were neutral, 40.0 percent disagreed while 17.0 percent strongly disagreed. This implies that majority of the respondents disagreed that debts due can be paid within the next 12 months.

Finally, the findings obtained data on whether the banks credit risk strategy reflects the banks tolerance for risk. The results of data analysis results shows that majority 46.0 percent of respondents agreed while 10.0 percent strongly agreed that the banks credit risk strategy reflects the banks tolerance for risk. But 8.0 percent were neutral, 7.0 percent disagreed while 29.0 percent strongly disagreed. This implies that slight majority of the respondents Agreed that the banks credit risk strategy reflects the banks tolerance for risk.

\section{Inferential Statistics}

Based on the study, inferential statistics was done on the quantitative data. The statistics done included correlation, regression and ANOVA. The results are presented in the section below.

\section{Effects of liquidity of banks performance in Kenya Correlation}

The study analysed data on the effects of liquidity of banks performance in Kenya to obtain the Pearson correlation and presented the results in Table 4:2.

Table 4.2 Pearson Correlation of effects of liquidity of banks performance in Kenya

\begin{tabular}{lll}
\hline Variable & Test & Banks performance \\
\hline \multirow{2}{*}{ Liquidity } & Pearson Correlation & $.835^{* *}$ \\
& Sig. (2-tailed) & .000 \\
& $\mathrm{~N}$ & 42 \\
\hline
\end{tabular}

**. Correlation is significant at the 0.01 level (2-tailed). 
The study shows that liquidity has positive relationship on of banks performance. The $r$ value is 0.835 which is relative strong at 2 tailed significance of 0.000 which is below 0.01 significant levels.

\section{Regression}

From the study again, a regression was done on quantitative data between liquidity on banks performance and presented the findings in the Table 4:3.

Table 4.3 Coefficientsa Determination of effects of liquidity on banks performance in Kenya

\begin{tabular}{|c|c|c|c|c|c|}
\hline \multirow[t]{2}{*}{ Model 1} & \multicolumn{2}{|c|}{ Unstandardized Coefficients } & \multirow{2}{*}{$\begin{array}{l}\begin{array}{l}\text { Standardized } \\
\text { Coefficients }\end{array} \\
\text { Beta }\end{array}$} & \multirow[t]{2}{*}{$\mathbf{t}$} & \multirow[t]{2}{*}{ Sig. } \\
\hline & $\mathrm{B}$ & Std. Error & & & \\
\hline (Constant) & 2.664 & .182 & & 42.309 & .000 \\
\hline Effects of liquidity & .310 & .356 & .308 & .762 & .389 \\
\hline
\end{tabular}

a. Dependent Variable: Banks performance

Table 4:3 provides the information needed to banks performance from effects of liquidity. Both the constant and liquidity contribute significantly to the model. The regression equation is presented as follows; (Y) Banks performance $=2.664+0.310$ (Liquidity).

\section{Model Summary}

The model summary of the relationship of liquidity against banks performance is presented in Table 4.4 .

Table 4.4 Model Summary of liquidity on banks performance

\begin{tabular}{lllll}
\hline Model 1 & R & R Square & Adjusted R Square & Std. Error of the Estimate \\
\hline & $.390^{\mathrm{a}}$ & .136 & .072 & .498 \\
\hline
\end{tabular}
a. Predictors: (Constant), liquidity

Table 4:4 provides the $\mathrm{R}$ and $\mathrm{R} 2$ value. The $\mathrm{R}$ value is 0.39 , which represents the simple correlation. It indicates an average degree of correlation. The R2 value indicates how much of the dependent variable, "banks performance ", can be explained by the independent variable, " liquidity". In this case, 13.6 percent can be explained, which is relatively significant.

In summary

$$
Y=\beta_{0}+\beta_{1} X_{1}+e
$$

By replacing the values

(Y) Banks performance $=2.664+0.310$ (Liquidity)

Multiple regressions give the constant as

Therefore, the overall regression model is

(Y) Banks performance $=2.664+0.310$ (Liquidity)

Statistical analysis shows that liquidity has highest effect on banks performance, followed by management efficiency, risk analysis then monitoring and control.

Based on these findings:

The null hypothesis $\mathrm{H}_{01}$ : Liquidity does not have statistically significant influence on of banks performance in Kenya: is rejected Therefore, liquidity has a significant influence on of banks performance in Kenya. 


\section{CONCLUSION AND RECOMMENDATION}

According to Jamaat and Asgari (2010), Liquidity held by commercial banks depicts their ability to fund increases in assets and meet obligations as they fall due. Liquidity is one of the important financial stability indicators since liquidity shortfall in one bank can cause systemic crisis in the banking sector due to their interconnected operations. Results on determine the effects of liquidity of banks performance in Nairobi city, the respondents were asked to indicate the level of agreeableness for liquidity on banks performance in Kenya and the findings are present. majority of respondents agreed that banks have a sound credit management system and that the bank holds liquid assets which are diversified. The results of the study revealed that majority of the respondents agreed that the bank hold cash (direct) bonds, as well as making extensive use of derivatives which are similarly compared with other banks and the bank receive regular flows from borrowers and has adequate cash equivalents to meet demand any time together with the staff having experience on dealing with previous liquidity issues. Further, the findings also indicated that majority of the respondents disagreed that debts due can be paid within the next 12 months and that slight majority of the respondents Agreed that the banks credit risk strategy reflects the banks tolerance for risk.

In conclusion basing on the findings, the hypothesis $\mathrm{H}_{01}$ : Liquidity does not have statistically significant influence on of banks performance in Kenya: is rejected Therefore, liquidity has a significant influence on of banks performance in Kenya.

Based on the findings, the study recommended the following; the management of commercial banks should use the credit risk strategy suitably to reflect the banks tolerance for risk and also have adequate cash and equivalents to meet demand any time.

The bank should take into consideration potential future changes in economic conditions when assessing individual credits and their credit portfolio.

The management should have a proper system for monitoring the condition of individual credits, including determining the adequacy of provisions and reserves by employing an information systems and analytical techniques that enable management to measure the credit risk inherent in all on-and off-balance sheet activities.

The management of should make sure that banks operate within sound, well-defined creditgranting criteria by both providing and communicating timely and adequate information system on composition of credit portfolio.

\section{References}

Abiola, I., \& Olausi, A.S. (2014). The Impact of Credit Risk Management on the Commercial Banks Performance in Nigeria. International Journal of management and Sustainability. 3(5):295-306

Aburime, U. (2005). Determinants of Bank Profitability -Level Evidence from Nigeria. University of Nigeria: Unpublished MBA Research Project.

Achou, F. C. (2008). Bank performance and credit management, Master degree project. University of Skovde,Spring term : Spring Term,.

Afriye ,H.O. \& Akotey,J.O.(2013).Credit Risk Management and Profitability of selected rural banks in Ghana.Ghana catholic university College of Ghana

Alexandru, C. G. (2008). The assessment of banking Performances-Indicators of Performance in Bank Area. .MPRA Paper No. 11600.

Al-Tamimi, H. (2010). Factors Influencing Performance of the UAE Islamic and Conventional National Banks. Global Journal of Business research, 4(2),1-9.

Bank, W. (2013). World Development indicators,. New York: Oxford University Press. 
Berger A, H. R. (1995). The role of capital in financial institutions. Journal of BankinggandFinance.,Pp.393430.Availableat.Retrievedfromhttp://www.Sciencedirect.com/science/article/pii/037842 669500002X (Accessed 8 April 2016)

Basel Committee on Banking Supervision (1999).Credit risk modelling:Current Practice and applications.Mimeo

Bikker, J.A. \& Metzemakers, P.A.J., 2005. "Bank provisioning behaviour and procyclicality," Journal of International Financial Markets, Institutions and Money, Elsevier, vol. 15(2), pages 141-157, April.

Baltagi, B.H. (2005). Econometric Analysis of Panel Data. England: John Wiley and Sons Ltd, The Atrium, Southern Gate, Chichester, West Sussex P019 8SQ.

Central Bank of Kenya (2005),Bank Supervision Annual Report. CBK Nairobi

6tg323Bryman A, Bell E. (2003).Risk Business Research Methods Oxford University Press

Central Bank of Kenya(2016). Bank Supervision Annual Report. CBK Nairobi

Christopher,J. (1996).Scholarly article on "an analysis of commercial bank exposure to credit risk" Wharton school center for financial institutions

Coyle, B. (2000). Framework for Credit Risk Management, London: Chartered Institute of Bankers

Dan, Uyen (2011).The CAMEL Rating System in Banking Supervision: a Case Study of Arcada University of Applied Sciences, International Business

Dang,U.(2011),The CAMEL Rating System in Banking supervision: a Case Study dissertation,Arcada University of applied Sciences, International Business.

Doliente, J.S. (2003). Determinants of Bank Net Interest Margins of Southeast Asia, retrieved from http://www.upd.edu.ph/ cba/docs/dp0310_jsd.PDF

Flamini, V. M. (2009). The determinants of commercial banks profitability in Sub-Sahara Africa.IMF Working paper $W P / 09 / 15$.

Gakure R.W., Ngugi, J.K., Ndwiga P.M., Waithaka, S.M. (2012). Effect of credit risk management techniques on the performance of unsecured bank loans employed commercial banks in Kenya. International Journal of Business and Social Research (IJBSR), Volume -2, No.-4.

Githaiga, J. (2013). Effects of credit risk management financial performance of commercial banks in Kenya.g hnjmk, Grier, W. A. (2007). Credit analysis of financial institutions. Euromoney Books. (2nd ed.). Euro Money Institutional Investors, PLC.

Gujarati, D. N. (2003). Basic Econometrics. 4th. New York: McGraw-Hill.

Haneef, S., Riaz, T., Ramzan, M., Rana, M. A. Ishaq, H. M. and Karim Y. (2012). Impact of Risk Management on NonPerforming Loans and Profitability of Banking 54 Sector of Pakistan. International Journal of Business and Social Science Vol. 3 No. 7.

Ismal, R. (2010). The management of liquidity risk in Islamic Banks: the case of indonesia (Doctoral dissertation, Durham University).

IMF Annual Report 2009

Jamaat, A., \& Asgari, F. (2010). "Credit risk management in banking system with data mining approach", quarterly magazine of quantity studies in management, 1(3):115-126

Kane, E. \&. (1998). Bank runs and banking-Lessons for African Policy Makers. Journal of Money, Credit and Banking, 2(1),, 26-35.

Kenya, C. B. (2013). Prudential Guideline for Institutions Licenced under banking Act. CBK ACT, CBK/PG/03,82-124.

Kerlinger,F.N.(1986),Foundation of Behavioral Research,(3 $3^{\text {rd }}$ edition)Fort worth; Holt, Rinehart and Winestone inc, pp102

Kimeu, T. (2006). Survey of Credit Risk Management techniques of unsecured Bank Loans of commercial Banks in Kenya. . Unpublished MBA Reaserch Project University of Nairobi.

Kimeu, T. (2006). Survey of Credit Risk management techniques of unsecured Bank Loans of commercail banks in Kenya . Unperblished MBA Reserach project University of Nairobi.

Kithinji, A. (2010). Credit Risk management and profitability of commercial banks in Kenya(University of Nairobi school of Business). 
Khumbakar K. Cetorelli, N., and M. Gambera (2001) Banking Market Structure, Financial Dependence and Growth: International Evidence from Industry Data," Journal of Finance 56, 617-648

Kombo, D. K., \& Tromp, D. L. (2006). Proposal and thesis writing: An introduction. Nairobi:Paulines Publications Africa Krawish, H. (2011). Determinants of commercial banks performance: Evidence from Jordan. International Reaserch Journal of Finance and Economics.Zarqa University,, 5(5), 19-45.

Kumbhakar, S.C., C. Lovell A. K. (2003).Stochastic Frontier Analysis Cambridge University Press

Lyman, .. \&. (n.d.). Introduction to business enterprise, (Fourth Edition ed.). Keong Printing Company PTE Limited,. Markowitz, H. (1952). Portfolio Selection. Journal of Finance, 12, 71-91.

Muasya, B. W. (2009). The impact of non-performing loans on the performance of banking sector in Kenya, . University of Nairobi: unpublished MBA project,

Mugenda, O. \&. (2003). Reaserch methods. Acts press Nairobi.

Murthy, Y... (2003). A study of Financial Rations on major commercial banks. Journal of Academy of Business and Economics, 12(3), 10-15.

Naceur,S.B.\& Goaied,M.(2008),The Determinants of the Tunisian Deposit Banks' Performance, Journal of Applied Financial Economics,11(3),317-319.

Nyongo,J N.(2014)The relationship between credit risk management and non -performing loans in commercial banks in Kenya. University of Nairobi. Unpublished Masters Thesis

Obamuyi, T. (2013). Determinants of banks profitability in developing econimies: evidence from Nigeria . Organisation and market in emerging economies,volume no 2(8), 97-111.

Olweny, T. \&. (2011). Effects of Banking Sectorials Factors on Banking Profitability of commercial banks in Kenya. Economics and Finance Review,1(5), 1-30.

Ongore, V. (2013). Determinants of Financial Performance of Commercial Banks in Kenya . International Journal of Economics and Financial Issues:ISSN:2146-4138.

Ongore, V. O., \& Kusa, G. B. (2013). Determinants of financial performance of commercial banks in Kenya.International Journal of Economics and Financial Issues, 3(1), 237.

Oladele,et al (2012).Determinants of Bank Performance in Nigeria. Internal Journal of Business and Management Tomorrow,2 (2),1-4

Orodho J.A. (2005).Elements of Education and Social Science Research Methods, Kanezja Publishers

Oso, W. Y., \& Onen, D. (2009). A general guide to writing research proposal and report. Nairobi: Jomo Kenyatta Foundation.

Parry, C. (1999). Lending and securities: A Practical Guide to the principles of Good lending,. Kenwood Books LTD,.

Saunders and Cornett(2007).Financial Institution Management.McGraw Hill Pub.2005

Saona, P.H. (2011).Determinants of profitability of the US Banking Industry. International Journal of Business and Science, 2 (22),255-269

Sinkey, J. (2002). Financial Markets and Institutions: An Introduction to the Risk management Approach, . McGraw Hill Pub, 1(2),36-49.

Sufian, F. \&. Habibullah, M.S.(2009). Determinants of Bank profitability in a developing economy:Emperical evidence from Bangladesh. Journal of Business Economics and Management,10(3), 207-217.

Wen, W. (2010). Ownership structure and banking performance: New evidence in China,. University of Barcelona.: unpublished masters Thesis, .

Wong, T. C., Wong, J., \& Leung, P. (2009). The foreign exchange exposure of Chinese banks. China economic review, 20(2), 174-182

Zouari, A. (2010). Efficient Strucure verses Market Power: Theories and Emperical Evidence. International journal of Economics and Finance.2(4), 151-166. 